\title{
The Urgency of Writing Scientific Papers for Tutors in Non-Formal Education Units (SPNF) in the Region 1 of Padang City
}

\author{
Wirdatul Aini \\ Department of Non-Formal Education \\ Universitas Negeri Padang, Indonesia \\ wirdatulaini@fip.unp.ac.id
}

\begin{abstract}
The skills training for the society is motivated by the low ability of the tutors to write scientific work in the Non-Formal Education Unit (SPNF) in the region of Padang City. The purposes of scientific writing skills training are able to: (1) theoretically, to understand the methods of scientific writing, (2) theoretically, to write scientific works in accordance with scientific steps, and (3) practically, be able to write scientific/real work in the framework of developing a career as a tutor of learning. Speech, question and answer, discussion, and training methods are the methods that will be used in this training. The speech and question-answer methods are used to provide counseling and skills training to the tutors. Discussion is used to the fellow participants to learn each other and discuss the training material delivered by the instructor. Whereas, training is used to improve tutors learning a skill in writing scientific papers. The results obtained from this training that most of the tutors were able to: (1) theoretically, understand the methods of writing scientific, (2) theoretically write scientific papers based on the scientific steps, and (3) practically able to write scientific/real work in the context of developing careers as tutors for learning.
\end{abstract}

Keywords: urgency, writing, scientific papers, tutors

\section{INTRODUCTION}

The Non-Formal Education Unit (SPNF) is a Regional Technical Service Unit (UPTD) in the field of Non-Formal Education activities under the Ministry of National Education. (SPNF) carry out learning activities for people who are not served by the school education system, and the learning targets served by outside school education are for those who have never received formal education, dropped out of school, and for those who have completed formal education but want to add skills through non-formal education (Aini 2006). As a technical implementation unit in the field of education, SPNF has a very big role in providing educational services in the community in the form of adult education, early childhood education, youth education, life skills education for the community that suits for their needs.

In implementing a work program at SPNF is led by a chief. The technical implementation of learning activities at SPNF is carried out by tutors. Tutor learning is an education staff in the field of non-formal education who was appointed as a civil servant at the UPTD, both appointed in the Regency/City, Province and Regional Level. Tutor learning in general has a job for facilitating a learning activity so that the learning process outside of school can run optimally. Besides that, the tutor is required to be an organizer and motivator in a learning activity so as to create the condition conductively for the implementation of learning activities at SPNF.

According to Permenpan number 15 of 2010 the Functional Position of the learning service is a position that has scope, duties, responsibilities and authority to carry out teaching and learning activities, study programs, and develop models of non-formal and informal education (PNFI) in Technical Implementation Units (UPT), Regional Technical Implementation Units (UPTD) and
PNFI units based on laws and regulations occupied by civil servants. Tutor learning is an educator with the main task of conducting teaching and learning activities start from planning the end of the evaluation, follow-up on program studies, the development of non-formal and informal education (PNFI), technical implementation units region (UPTD) and PNFI unit.

For the development of civil service learning based on Permenpan Number 15 of 2010 Article 6 paragraph e, it was stated that the learning service is required to carry out professional assignments for the assessment of credit numbers as follows: (1) making scientific work in the PNFI field, and informal, (3) development of appropriate technology, art and sports works that are beneficial in the field of non-formal and informal education (PNFI), and (4) standard/guideline/questions, and etc.

Based on observations and interviews conducted by the author on January 13, 2018 with the Head of SPNF Region 1 in Padang City, most of the tutors studying at SPNF were still not mastered in making scientific work in the form of scientific writing/real work. As a tutor, they are required to be able to write scientific papers, so that their profession can develop and can be promoted to a higher level.

Based on the problems stated above, the author tries to find a solution to the problems faced by tutors by conducting scientific writing training/writing real work for tutors to study in SPNF Region I and hopefully the learning service will be helped by this training so that can develop their careers as tutor of learning.

Based on the background of the problem that has been raised, the purpose of this training activity is for the tutors to be able to: (1) theoretically understand the scientific work, (2) theoretically understand how to write 
scientific works with the steps, and (3) skilled in writing scientific works for professional development as tutors.

This training activity is beneficial for tutors in developing their profession as functional staff, so that they can be promoted to a higher level, the learning staff are expected can develop learning activities at SPNF, and it is useful to develop an innovative learning models at SPNF (Androulaki et.al, 2017; Vovk et.al, 2019).

Scientific writing is a series of writing activities that are based on scientific research or research written systematically using the language of scientific principles, or someone who claims that scientific papers are written based on scientific criteria. Based on Eko Susilo, (1995), scientific papers are essays or writings obtained in accordance with scientific and based on the results of observations, review of research, in certain fields, arranged according to certain methods with systematic writing in language and its contents can be accounted for its correctness.

The purposes of writing scientific papers are as follows: (1) as a mode for training in expressing their thoughts or research results in the form of systematic and methodological scientific writings, (2) fostering a scientific ethos so that they are not consumers of science, but also producers thoughts and papers in the field of science, (3) it will be expected that written scientific become a transformation of knowledge between schools and the community or people who intend to read it, (4) prove the potential and scientific insight someone has in dealing with and solve problems in the form of scientific work after the concerned has acquired knowledge, and (5) train basic skills to conduct research.

Thus, a scientific work must show the characteristics of scholarship, both in its character, and in terms of its language. In terms of the character must fulfill the following elements: (1) logically in terms of sound thinking, (2) objective in the sense that scientific writing activities are based and accompanied by data and facts, are informative, descriptive and free of interests subjective, (3) empirically in the sense of writing in the area of human experience, and (4) systematic in the sense that scientific papers have criteria in selecting the problems to be raised, namely: To start writing must begin by raising problems in around the environment, starting the problems from simple to the most complex. The scope of the problem must be from small to large scope and from limited scope to the widest scope (wordpress.com 2012). Problems raised must be actual, important and necessary.

Based on Minister of Finance Regulation No. 15 of 2010 concerning tutor learning functional positions and credit numbers, chapter e no. 3 describes the tutor learning as developing appropriate technology, art and sports that are useful in the field of non-formal education. Furthermore, the Permenpan also explained that the main of the learning service to study the programs and develop models in the field of non-formal and informal education. Based on the statement, the scientific papers carried out by the tutor learning are more focused on writing real work.

Kemendikbud (2011) stated that the real work is an innovative work in creating designs, technology models/works open opportunities for businessman/work that help the community. The real work aims to find a discussion in the fields so as to generate new passion in doing work both for those who want to find and for others.

Systematics and real writing are the same as regular scientific writing. The systematic are: title of program, background of the problem, formulation of the problem, the purpose of the problem, expected output/results, program usability, business plan overview, literature review, program implementation methods, findings and discussion explaining the resulting product in the form of inptex application, model development, entrepreneurship, community service, and conclusions. For more details, the following explanation will be described of the systematic in question according by Hanum, Farida 2009, and FIP 2012: (1) the title, the specific brief is clear enough to illustrate the activities carried out, (2) the background of the problem points out the things that encourage the importance of the activities carried out

Describe the identification of the problem process will find a solution. Describe a brief view of other writers who have discussed topics related to references to various library sources, and quantitatively portray the profile and condition of the target audience, (3) formulation of the problem, clearly the problem to be solved, and explain the scope of the activity, (4) program objectives; is a brief statement about the purpose of the activity, the formulation of objectives specifically is a new condition that is expected to be realized after the activity is carried out, and the formulation of objectives should be clear and measurable, output expected from this program in the form of patents, models, designs, goods and services, (5) literature review; (a) try the latest, relevant and original literature, (b) describe clearly the literature review that raises ideas and underlies the activities carried out, (c) the literature review outlines the theories, findings and research materials that are used as the basis for activities, (6) the usefulness of the program, describe the benefits obtained for the target audience in terms of economics and science and technology, (6) implementation methods, describe the methods used in implementing the program in detail to achieve planned objectives, (7) findings and discussion in detail in the form of the application of science and technology, entrepreneurship, community service or the development of learning models in nonformal education, and other innovative works, (8) conclusions are to conclude technology produced based on real work made, and (10) reports complete with the most recent bibliography used to write real work and if you can use the source of results research that has been developed by researchers.

\section{METHOD}

The scientific/real work writing skills training activities are carried out in two forms, namely counseling and training. Counseling is to provide information, an explanation to the tutor to learn about scientific real work, for this reason the lecture method is used, and question and answer (Mingazova and Volchkova, 2019). The discussion method is used to provide opportunities for the 
tutor to discuss, learn from each other about the material of scientific/real work delivered by the instructor. The training activity is to provide opportunities for the tutors to learn to do, and practice to write scientific works, and in this case the training is more focused on real work writing, for this reason a guided training method is used, meaning the tutors learn to write real work directly given guidance by instructors/implementers training.

The success of this activity can be seen in terms of processes and results. In terms of process the results measured are the intensity of participants' participation, creativity and enthusiasm in the training process. The technique used for evaluating this process is observation and administration of activities (attendance of participants).

In terms of results (products) that are measured is the acquisition of knowledge, skills, and attitudes of participants in producing scientific work and real work. In this case the test technique is used to measure the knowledge of the civil service to learn about scientific work, while to measure the learning skills of the tutor in writing scientific/real work is the paper produced/written by the tutor.

\section{RESULT AND DISCUSSION}

The results of the activities are the presentation of the material delivered by the instructor and the participants' understanding of the material presented by the instructor. Understanding of material by participants can be seen/observed from; participants' participation in the activity was proven by the presence of participants in the activity, the results of the tests conducted and from the actual work of the tutors. For more details the results achieved in the scientific/real work writing training service activities and the discussion will be described below:

Based on the results of observations on the implementation of the presentation of material on scientific writing, it was seen that the enthusiasm of the civil service learned in the activity, this was evidenced by the attendance of the participants in the activity, all participants attended $(100 \%)$ in participating in the activity. At the time of presentation of material by the instructor, the participants responded actively and ask the questions about the material presented by the instructor. The materials presented by the instructor are: (1) the method of writing scientific papers, (2) the application of scientific writing. The participants seemed to have begun to understand the method of writing scientific papers, and this was shown from the results of a question and answer test conducted at the time of the process of the activity and seen from the results of the written test by the tutor.

The presentation of scientific writing material presented by the instructor, it was observed that $75 \%$ participants had begun to understand the scientific writing techniques. According to there are two scientific papers in general by Yaniawati in 2015, and Fahri, 2017 namely scientific papers based on the results of research and scientific papers based on literature studies only. In writing scientific papers, both the results of research or literature studies, $65 \%$ the tutors have begun to understand the steps in writing scientific papers, namely:
(1) the background is explained clearly how important the problems raised are discussed, and the problems raised are supported by data. On this background, problems will be formulated that will find a solution. As large as $80 \%$ of participants already understand formulating the problem (2) the goal is, relating to what will be achieved after the activity is carried out. The goal is to become a basic requirement in every scientific paper making, some $60 \%$ of participants have been able to smooth out the objectives of scientific work (3) theoretical basis is the opinion of experts related to the problems carried out and theoretical studies that support the arguments put forward, almost $70 \%$ of learning officials have been able to refine the study of expert opinion theory quoted according to scientific writing how to cite, punctuation, language, etc. (4) methodology is how to find research results from literature studies for scientific papers that are not the results of the research, almost $75 \%$ of the tutors have been able to understand the method of scientific work (5) the benefits of the research are well presented in terms of the benefits of scientific writing, (6) the results of the research are found in the literature or from reading sources that support solving problem raised. From the instructor's explanation of the steps in writing scientific papers it was observed that most $70 \%$ of the tutors learned to understand the steps in writing scientific works that were appropriate to the methods of scientific writing.

The presentation of the real work explained by the instructor in general was understood by the participants, and this was observed from the enthusiasm of the participants following the counseling, then from the questions asked by the participants to the instructor, besides the results of tests conducted on the participants the results were good. Basically, the real work according to the Ministry of Education and Culture 2011 is innovative work in creating designs, models/technological works that open opportunities for business/work that help the community. The real work aims to find a renewal in the fields so as to generate new passion in doing work both for people who find and for others.

The real writing technique is basically the same as ordinary scientific writing; just a little difference, where in the real work there are products produced in the form of the application of science and technology, model development, entrepreneurship, community service works including real work. The material related to training or practice carried out by the tutors in writing real work is more focused because it is in accordance with the directions of the chief of the SPNF and also from the professional development of tutoring based on Permenpan number 15 of 2010 . Part (e) of the learning service is to produce scientific papers useful technology, arts and sports works that are useful in the field of Non-formal and Informal Education.

Based on observations while taking part in the tutoring learning training, they were motivated and began to be skilled in writing real work assigned by the instructor, even though the results obtained had not achieved maximum results. As we know that to write a scientific work requires practice repeatedly, requiring willpower, tenacity, and hard work (Hutabarat et.al, 2019). If such behavior is already possessed by the tutor, 
of course, the tutor in the development of his profession will succeed as expected. Hopefully with the training of scientific/real writing work this will lead to the motivation of the tutors to produce scientific papers/real works in order to support their profession as tutors.

\section{CONCLUSION}

Based on the scientific/real writing training activities for the tutors at the SPNF Region I in Padang City, it was concluded that the learning staff had high motivation in attending scientific/real writing training and this was evidenced by the high attendance of the tutors to participate in counseling and training activities. Theoretically, the tutor has understood the scientific and real writing techniques related to the development of his profession as a tutor of learning. Practically, the learning service provider has begun to be skilled in writing scientific/real papers. To be more skilled, continuous training is needed, the willingness, and perseverance needed in writing scientific/real writing is needed. Based on the conclusions stated in the previous section, the following suggestions will be conveyed, that the chief of SPNF will always encourage the learning staff to make scientific/real papers for the development of their profession as tutors of learning. It is expected that the chief of SPNF will program the development of the tutelary profession through scientific/real writing. It is expected that the tutors learn to practice writing scientific/real papers so that more skills are developed in writing scientific/real work.

\section{REFERENCES}

[1] Aini, W., Bahan Ajar Konsep Pendidikan Luar Sekolah, Padang: FIP UNP, 2006.

[2] Fahri, A., Sistimatika Karya Tulis Ilmiah, http://bloggueblok,wordpress.com , 2017.

[3] Hanum, F., Makalah Pelatihan Teknik Penulisan Karya Imiah Guru di Dinas Propinsi DIY, 2009.

[4] Kemendikbud, Penulisan Karya Nyata, Inovatif, Jakarta: Kemendikbud, 2011.

[5] Kemendiknas, Peraturan Mentri Negara Pendayagunaan Aparatur Negara dan Reformasi Birokrasi (Jabatan Fungsional Pamong Belajar dan Angka Kreditnya), Jakarta: Kemendiknas, 2010.

[6] Yaniawati, P., Makalah teknik Penulisan Karya Ilmiah, Disajikan pada Bimtek Penulisan karya Ilmiah bagi Dosen di Lingkungan Kopertis Wilayah IV. Sumedang-Jati Nangor, 2015.

[7] Androulaki, Eirini, Ioanna Kalliopi Georgoudi, Maria Margariti, Mitropoulou Xristoula, Mpakalou Paraskeui, and Eumorfia Papageorgiou. "Culture, tourism and community based university-the role of non-formal education in promoting lifelong learning, Training, local growth and prosperity." Journal of Regional \& Socio-Economic Issues 7, 2017.

[8] Vovk, M.P., Sotska, H.I., Trynus, O.V. and Muzyka, O.J., Assessment of Instructors' Technology Competency to Be Used in the Settings of Formal and Non-Formal Education. International Journal of Higher Education, 8(5), pp.29-44. 2019.

[9] Mingazova, D. R., and Volchkova, V. I.. Problems and Perspectives of the Carrier Counseling and Training of Graduates of the Volga Region Academy of Physical Culture, Sport and Tourism. In Актуальные проблемь физического воспитания студентов, pp. 46-49. 2019.

[10] Hutabarat, I.M., Palit, E.I. and Gultom, M., Pelatihan Dan Pendampingan Penulisan Karya Ilmiah Bagi Guru-Guru SMP di Sentani. Jurnal Pengabdian Papua, 3(2), 2019. 